\title{
Factors Associated with the Completeness of Inpatient Medical Record Filling in Dr. R Sosodoro Djatikoesoemo, Bojonegoro, East Java
}

\author{
Tegar Wahyu Yudha Pratama1), Didik Tamtomo²), Endang Sutisna Sulaeman²) \\ 1)Diploma III of Medical Records, School of Health Sciences \\ Muhammadiyah Bojonegoro, East Java \\ ${ }^{2)}$ Faculty of Medicine, Universitas Sebelas Maret
}

\begin{abstract}
Background: Medical records are central to all patient healthcare activities. Fundamentally, they form part of a doctor's ethical and statutory duty in providing good patient care.Good quality medical records, including completeness of record filling, are essential to proper ongoing care of the patient and are paramount for effective communication between healthcare professionals and their patients. However, studies in Indonesia examining factors associated with the completeness of inpatient medical record filling is scanty. The purpose of this study was to examine factors associated with the completeness of inpatient medical record filling in a district hospital.

Subjects and Method: This was a quantitative study using a cross-sectional design, conducted at Dr. R. Sosodoro Djatikoesomo Bojonegoro hospital, East Java, in April 2018. A total of 213 nurses working at the inpatient service ward was selected for this study by proportional random sampling, composing of 115 nurses with graduate degree and 35 nurses with diploma degree. The dependent variable was completeness of inpatient medical record filling. The independent variables were education level, employment status, tenure, responsibility, and organization support. The data were collected by questionnaire and document review. The data were analyzed by a multiple logistic regression.

Results: Completeness of inpatient medical record fillingwas positively associated with higher education $(\mathrm{OR}=2.94 ; \mathrm{CI} 95 \%=1.08$ to $8.00 ; \mathrm{p}=0.034)$, civil servant status of employment $(\mathrm{OR}=$ 4.01; CI 95\%=1.71 to 9.40; $\mathrm{p}=0.001), \geq 3$ year tenure $(\mathrm{OR}=8.84 ; \mathrm{CI} 95 \%=2.78$ to $28.16 ; \mathrm{p}<0.001)$, higher knowledge $(\mathrm{OR}=5.37$; $\mathrm{CI} 95 \%=1.40$ to $20.55 ; \mathrm{p}=0.014)$, stronger responsibility $(\mathrm{OR}=3.13$; CI $95 \%=1.35$ to $7.28 ; \mathrm{p}=0.008)$, and stronger organizational support $(\mathrm{OR}=4.08 ; \mathrm{CI} 95 \%=1.72$ to 9.67; $\mathrm{p}=0.001$ ).

Conclusion: Completeness of inpatient medical record fillingis positively associated with higher education, civil servant status of employment, $\geq 3$ year tenure, higher knowledge, stronger responsibility, and stronger organizational support.
\end{abstract}

Keywords: completeness, inpatient, medical record, filling

\section{Correspondence:}

Tegar Wahyu Yudha Pratama. School of Medical Records and Health, STIKES Muhammadiyah, Bojonegoro. Email: tegar.wahyu404@gmail.com. Mobile: +6285746085030.

\section{BACKGROUND}

Hospitals are the means of health care providers to the community which should be able to serve and meet the needs of the community. The increase of public awareness of the quality of health services causes hospitals to be able to provide services and maintain the quality of health services to patients. Good health care and quality cannot be separated from the role of medical and non medical personnel, including nurse. Nurses are in demand to provide health services in accordance with the standard of care of nursing and to record all of that in the medical record. Medical records have an important role to support quality 
and efficient care, incomplete documentation often occurs in many hospitals (Ufitinema et al., 2016).

Based on data from Setz and D'Innocenzo (2009) study conducted at the university hospital in SaoPaulo Brazil, the completeness of nursing documentation is $73.4 \%$ while $26.6 \%$ of it is incomplete. Ufitinema et al. (2016) study which was conducted in Rwanda-Africa hospital showed that the completeness of nursing documentation documentation reached $67 \%$ while $33 \%$ of it was incomplete. In addition, preliminary studies that have been done in Dr. R. Sosodoro Djatikoesoemo Bojonegoro hospital showed that medical record completeness on nursing care documentation inpatient in July and August 2017, the completeness rate still reached $75 \%$ and the rest $25 \%$ was still incomplete. This is in contrast to the regulation of the ministry of health No. 129 / MENKES / SK / II / 2008 on minimum hospital service standards, stating that completeness of medical record 24 hours after completion of service (with $100 \%$ complete or $0 \%$ incomplete).

Complete nursing care documenttation has some benefits in various aspects, such as legal aspects, quality assurance, communication, finance, education, research and accreditation (Nursalam, 2007). In addition, according to Jefferies et al, (2010) nursing care documentation is important because it defines the nature of nursing itself by documenting patient care outcomes.

The qualified nursing care will provide a sense of security and comfort to the patients and provide a positive effect on the healing of illness. According to the Ministry of health (2001) on the registration and practice of nurses, Nursing care standards include assessment, determination of nursing diagnoses, planning, implementing nursing actions and nursing evaluation.
The standard of nursing care must be filled and completed in the medical record after each patient's service. It is very beneficial to improve the quality of patients care and as a source of information on the provision of health services in hospitals.

The medical record can be statedas high quality, if the medical record can describe the whole process of the service correctly, completely, reliably, valid, timely, it can be used for analysis and decisionmaking, uniform, constraints on standardized elements consistent in its use, and easily obtained through communication systems between health workers (Sanjoyo, 2007).

The knowledge of medical personnel and paramedics is generally still low on the filling and utilization of medical records (Hutagalung, 2005). Less nurse obedience in applying documentation records of nursing care result in low quality complements of the medical record.

Based on the background above, the researchers are interested in conducting a study on the determinant of medical record completeness in nursing care documentation that includes education level, employment status, working period, knowledge, responsibility and organizational support (agency, on completeness of filling in nursing care documentation documentation in medical record at Dr. R. Sosodoro Djatikoesoemo hospital, Bojonegoro.

\section{SUBJECTS AND METHODS \\ 1. Study design \\ This was an analytic observational study with a cross sectional design. The study was conducted in Dr. R. SosodoroDjatikoesmo hospital Bojonegoro on April 2018.}

\section{Population and sample}

The population in this study was 213 nurses in Installation of Inpatient at Dr. R. Sosodoro Djatikoesmo hospital, Bojonegoro. 
The sample size was 150 nurses selected with proportional random sampling based on level of education (S1: 115, D3: 35).

\section{Study variables}

The independent variables of this study included the level of education, employment status, employment, employment status, responsibilities and organizational support while the dependent variable was the completeness of the documentation of nursing care inpatient care in the medical record.

\section{Operational definition of variables}

The level of education was defined as the highest level of formal education that has been taken by nurses at Dr. R Sosodoro Djatikoesoemo hospital, Bojonegoro, with a categorical data scale consisting of D3 and $\mathrm{S} 1$, as measured by questionnaires.

The employment status was defined as the nurse status as contract or permanent employee/civil servant in Dr. R Sosodoro Djatikoesoemo hospital Bojonegoro with a categorical data scale consisting of civil servants and non civil servants, as measured using questionnaires.

The period of work was defined as the length of time the nurse worked since assigned in Dr. R. Sosodoro Djatikoesoemo hospital Bojonegoro since the first day of work until the study was conducted. The measurement scale was categorical, coded o for $<3$ years and 1 for $\geq 3$ years. The data were measured using questionnaires.

Knowledge was defined as a person's knowledge that can be gained from education, training or experience derived from various sources, with a scale of categorical data consisting of good and lacking.

Responsibility was defined as the responsibility to bear including post control visits, or to provide responsibility for the consequences. The data were measured using questionnaires. The measurement scale was categorical, coded o for poor and 1 for good.

Organizational support was defined as the extent to which co-workers behave in supporting and strengthening employees by optimizing the use of employment knowledge, skills and attitudes on the job. The data were measured using questionnaires The measurement scale was categorical.

The completeness of the medical record of nursing care $\mathrm{i}$ was defined as $\mathrm{s}$ the documentation of nursing care (assessment, nursing diagnosis, nursing plan, implementation of nursing actions, evaluation, nurse's signature and nurse name, nursing resume, nursing record and patient record returning or dying on the contents of medical records. The data were measured by checklist. The measurement scale was categorical.

\section{Reliability Test}

Based on the reliability test on the variables of knowledge, responsibility and organizational support, the results can be seen in table 1.

\section{Data Analysis}

Univariate data analysis of categorical data sample was described using parameter $n$ and \%. Bivariate analysis was conducted using Chi Square. Multivariate analysis used a multiple logistic regression.

Table 1. Reliability Test of Questionnaire

\begin{tabular}{lcc}
\hline \multicolumn{1}{c}{ Variable } & Cronbach's Alpha & Conclusion \\
\hline Knowledge & 0.90 & Reliable \\
Responsibility & 0.85 & Reliable \\
Organizational Support & 0.83 & Reliable \\
\hline
\end{tabular}




\section{RESULTS}

The result of research subject characteristic in table 2 shows that the nurse age is mostly $<40$ years $(84 \%)$. The gender of the nurse was mostly women which was about 150 (66\%). The level of nursing education in duty inpatient care ward of $\mathrm{D}_{3}$ education background was 115 nurses (76.7\%). Staffing status of inpatient nurses in Dr. $\mathrm{R}$ Sosodoro Djatikoesmo hospital Bojonegoro still consists of a lot of non-civil servants for about 85 nurses (56.7\%). The most nurse work period is $\geq 3$ years for about 115 nurses (76.7\%). Besides, the nurse knowledge still lacked which is equal to 129 (86\%).

The responsibility of nursing inpatient at medical record is $83(55.3 \%)$. The organizational support in filling nursing care documentation is good for about 75 (50\%). The completeness of filling of inpatient nursing care documentation on medical record is more complete with 79 medical record file (52.7\%).

\section{Table 2.The characteristics of Subjects}

\begin{tabular}{|c|c|c|c|}
\hline Criteria & Classification & $\mathbf{n}$ & $\%$ \\
\hline \multirow[t]{2}{*}{ Age } & $<40$ years old & 126 & 84 \\
\hline & $\geq 40$ years old & 24 & 16 \\
\hline \multirow[t]{2}{*}{ Gender } & Male & 51 & 34 \\
\hline & Female & 99 & 66 \\
\hline \multirow[t]{2}{*}{ Educational background } & D3 & 115 & 76.7 \\
\hline & $\mathrm{S} 1$ & 35 & $23 \cdot 3$ \\
\hline \multirow[t]{2}{*}{ Employment status } & Non Civil Servant & 85 & 56.7 \\
\hline & Civil Servant & 65 & $43 \cdot 3$ \\
\hline \multirow[t]{2}{*}{ Working period } & $<3$ years old & 35 & $23 \cdot 3$ \\
\hline & $\geq 3$ years old & 115 & 76.7 \\
\hline \multirow[t]{2}{*}{ Knowledge } & Good & 21 & 14 \\
\hline & Poor & 129 & 86 \\
\hline \multirow[t]{2}{*}{ Responsibility } & Good & 83 & $55 \cdot 3$ \\
\hline & Poor & 67 & $44 \cdot 7$ \\
\hline \multirow[t]{2}{*}{ Organizational Support } & Good & 75 & 50 \\
\hline & Poor & 75 & 50 \\
\hline \multirow{2}{*}{$\begin{array}{l}\text { The completeness of } \\
\text { medical record } \\
\text { fulfillment }\end{array}$} & Incomplete & 71 & $43 \cdot 3$ \\
\hline & Complete & 79 & 52.7 \\
\hline
\end{tabular}

Table 3. Bivariate test of correlation between educational level, employment status, working period, knowledge, responsibility and organizational support to the completeness of filling in nursing care documentation documentation on medical record

\begin{tabular}{|c|c|c|c|c|c|c|}
\hline \multirow{3}{*}{ Variable } & \multirow{3}{*}{ Category } & \multicolumn{4}{|c|}{ The Service Quality } & \multirow{3}{*}{$\mathbf{p}$} \\
\hline & & \multicolumn{2}{|c|}{ Lack } & \multicolumn{2}{|c|}{ Good } & \\
\hline & & $\overline{\mathbf{N}}$ & $\%$ & $\bar{n}$ & $\%$ & \\
\hline \multirow{2}{*}{ Employment status } & Non Civil Servant & 52 & 61.2 & 33 & 38.8 & $<0.001$ \\
\hline & Civil Servant & 19 & 29.2 & 46 & 70.8 & \\
\hline \multirow{2}{*}{ Working period } & $<3$ years old & 29 & 82.9 & 6 & 17.1 & $<0.001$ \\
\hline & $\geq 3$ years old & 42 & 47.3 & 73 & 63.5 & \\
\hline \multirow{2}{*}{ Knowledge } & Low & 66 & 51.2 & 63 & 48.8 & 0.020 \\
\hline & High & 5 & 23.8 & 16 & 76.2 & \\
\hline \multirow[t]{2}{*}{ Responsibility } & Poor & 40 & 59.7 & 27 & 40.3 & 0.006 \\
\hline & Good & 31 & $37 \cdot 3$ & 52 & 62.7 & \\
\hline Organizational & Poor & 44 & 58.7 & 31 & 41.3 & 0.005 \\
\hline Support & Good & 27 & 36.0 & 48 & 64.0 & \\
\hline
\end{tabular}


Table 4. The results of bivariate analysis on the factors associated with the completeness of inpatient medical record filling

\begin{tabular}{|c|c|c|c|c|c|c|}
\hline \multirow{3}{*}{ Variable } & \multirow{3}{*}{ Category } & \multicolumn{4}{|c|}{ Quality of service } & \multirow{3}{*}{ p } \\
\hline & & \multicolumn{2}{|c|}{ Poor } & \multicolumn{2}{|c|}{ Good } & \\
\hline & & $\mathbf{N}$ & $\%$ & $\underline{\mathbf{n}}$ & $\%$ & \\
\hline \multirow{2}{*}{ Working status } & Private & 52 & 61.2 & 33 & 38.8 & $<0.001$ \\
\hline & Civil servants & 19 & 29.2 & 46 & 70.8 & \\
\hline \multirow{2}{*}{ Tenure } & $<3$ tahun & 29 & 82.9 & 6 & 17.1 & $<0.001$ \\
\hline & $\geq 3$ tahun & 42 & $47 \cdot 3$ & 73 & 63.5 & \\
\hline \multirow{2}{*}{ Education } & Low & 66 & 51.2 & 63 & 48.8 & 0.020 \\
\hline & High & 5 & 23.8 & 16 & 76.2 & \\
\hline \multirow[t]{2}{*}{ Responsibility } & Poor & 40 & 59.7 & 27 & 40.3 & 0.006 \\
\hline & Good & 31 & $37 \cdot 3$ & 52 & 62.7 & \\
\hline \multirow{2}{*}{$\begin{array}{l}\text { Organizational } \\
\text { support }\end{array}$} & Poor & 44 & 58.7 & 31 & 41.3 & 0.005 \\
\hline & Good & 27 & 36.0 & 48 & 64.0 & \\
\hline
\end{tabular}

Table 3 showed that the educational level of bachelor degree for nurse in completing the filling of nursing care documentation on medical record was better $(77.1 \%)$ than the nurses with diploma degree (45.2\%). The result of analysis showed that there was a positive and significant relationship between educational level and the completeness of inpatient medical record filling.

Civil servant status of employment in completing the filling of documentation of nursing care on inpatient medical record was better (63.5\%) than non-civil servant nurse (17.1\%). The result of analysis showed that there was a positive and significant relationship between employment status and the completeness of inpatient medical record filling.

The tenure $\geq 3$ years in completing the nursing care documentation on inpatient medical record was better (64.8\%) than the tenure of nurse $<3$ years $(21 \%)$. The result of analysis showed that there was a positive and significant relationship between the tenure and the completeness of inpatient medical record filling.

A good nurse's knowledge in completing nursing care documentation on inpatient medical record was better (76.2\%) than nurses with lack of knowledge (48.8\%). The result of analysis showed that there was a positive and significant relationship between knowledge and the completeness of inpatient medical record filling.

Good nurse's responsibility in completing nursing care documentation on inpatient medical records was better (62.7\%) than nurses with less responsibility (40.3\%). The result of analysis showed that there was a positive and significant relationship between responsibility and the completeness of inpatient medical record filling.

Strong organizational support to nurses in completing the filling of nursing care documentation on inpatient medical records was better (64.0\%) than low organizational support to nurses (41.3\%). The result of analysis showed that there was a positive and significant relationship between organizational support and the completeness of inpatient medical record filling. 
Journal of Health Policy and Management (2018), 3(1): 1-10

https://doi.org/10.26911/thejhpm.2018.03.01.01

Table 5. The results of multivariate analysis on the factors associated with the completeness of inpatient medical record filling using multiple logistic regression

\begin{tabular}{lcccc}
\hline \multicolumn{1}{c}{ Variable } & \multirow{2}{*}{ OR } & \multicolumn{2}{c}{ 95\% CI } & \multirow{2}{*}{ p } \\
\cline { 3 - 4 } & & Lower & Upper & \\
\hline Educational $\geq$ Senior high school & 2.94 & 1.08 & 8.00 & 0.034 \\
Employment status (civil servant) & 4.01 & 1.71 & 9.40 & 0.001 \\
Tenure ( $\geq$ 3 years) & 8.84 & 2.78 & 28.16 & $<0.001$ \\
Good knowledge & 5.37 & 1.40 & 20.55 & 0.014 \\
High responsibility & 3.13 & 1.35 & 7.28 & 0.008 \\
Good organizational support & 4.08 & 1.72 & 9.67 & 0.001 \\
N observation = 150 & & & & \\
-2 Log Likelihood= 142.2 & & & & \\
Nagelkerke R Square= 47.1\% & & & & \\
\hline
\end{tabular}

Based on Table 4, the results of multiple logistic regression equations can be explained as follows:

The level of education affected the completeness of the filling of inpatient nursing documentation on the medical record which was statistically significant. The education level of the nurses who have bachelor degree has 2.94 times probability in filling completely than the diploma III nurses $(\mathrm{OR}=2.94 ; 95 \% \mathrm{CI}=1.08$ to 8.00 ; $\mathrm{p}=0.034)$.

Employment status affected the completeness of inpatient nursing care documentation in the medical record and it was statistically significant. Civil servant status of employment has 4.01 times probability to fill completely than non-civil servant nurses $(\mathrm{OR}=4.01 ; 95 \% \mathrm{CI}=1.71$ to 9.40; $\mathrm{p}=0.001$ ).

Tenure affected the completeness of inpatient nursing care documentation in the medical record and it was statistically significant. Nurse's tenure of $\geq 3$ years was 8.84 times more likely to fill completely than nurses who worked for $>3$ years $(\mathrm{OR}=$ 8.84; $95 \% \mathrm{CI}=2.78$ to 28.16 ; $\mathrm{p}<0.001$ ).

Knowledge affected the completeness of inpatient nursing care documentation in the medical record and it was statistically significant. Good nurse's knowledge has
5.37 times probability to fill completely than nurses who have poor knowledge $(\mathrm{OR}=5.37 ; 95 \% \mathrm{CI}=1.40$ to $20.55 ; \mathrm{p}=$ 0.014).

Responsibility affected the completeness of the filling of inpatient nursing documentation on the medical record which was statistically significant.Nurses with good responsibility were 3.13 times more likely to fill completely than nurses who have lack of responsibility $(\mathrm{OR}=3.13$; $95 \% \mathrm{CI}=1.35$ to $7.28 ; \mathrm{p}=0.008$ ).

Organizational support affected the completeness of the filling of inpatient nursing documentation on the medical record which was statistically significant. Nurses with good organizational support have 4.08 times likelihood to fill completely than nurses who have lack of organizational support $(\mathrm{OR}=4.08 ; 95 \% \mathrm{CI}=1.72$ to 9.67 ; $\mathrm{p}=0.001$.

The score of Negelkerke R Square was 47.1\%, which mean that the five independent variables (educational level, employment status, tenure, knowledge, responsibility and organizational support) were able to explain the factors that affect the completeness of filling in inpatient nursing care documentation at medical record of $47.1 \%$ and the rest was $52.9 \%$ 
which explained by other factors outside the study.

\section{DISCUSSIONS \\ 1. The effect of educational level on the completeness of inpatient nursing care filling on medical record.}

The result of this study showed that educational level variable of nurses affected the completeness of inpatient nursing care filling on medical record, and it was statistically significant.

The result of this study was in line with Pratiwi et al, (2014), who stated that there was a relationship between nurses' educational levels and the completeness of nursing care documentation filling. Nurses who have bachelor degree and Nerscan completely filled the documentation assessment of nursing care than the D3 nurses. A study by Moradi et.al, (2014) stated that there was a significant relationship between educational level and the work quality of nurses. In addition, a study by Okaisu et al, (2014) indicated that staff training was insufficient to achieve better nursing care documentation, therefore, an ongoing improvement in education was needed.

\section{The effect of employment status on} the completeness of inpatient nursing care filling on medical record

The result of this study showed that employment status variable of nurses affected the completeness of inpatient nursing care filling on medical record, and it was statistically significant.

The result of this study was in line witha study by Maryati (2017) which stated thatthe quality of medical record documents filled by civil servant nurses was more complete (70\%) compared to noncivil servant nurses (57.8\%). In addition, according to Triyanto and Kamalludin
(2008), civil servant nurses were more responsible for the completeness of nursing documentation. This was also in line with a study by Dehghan et al, (2013) which stated thatnurses who had higher employment status after intervention experienced an increase in nursing records from $25.8 \%$ to $36.6 \%$.

3. The effect of tenure on the completeness of inpatient nursing care filling on medical record

The result of this study showed that tenure variable of nurses affected the completeness of inpatient nursing care filling on medical record, and it was statistically significant.

The result of this study was in line witha study by Kumajas et al, (2014), which stated that there was a meaningful relationship between tenure and nurse's performances. This was supported by a study by Sofiana and Purbadi (2006) in Kumajas et al. (2014) which stated that nurses with a tenure of $\geq 3$ years have better knowledge than nurses who have a tenure of $<3$ years. According to Nursalam (2009), the longer the nurse's tenure, the more the nurse's experiences in providing nursing care in accordance with the applicable standards or procedures.

\section{The effect of knowledge on the completeness of inpatient nursing care filling on medical record}

The result of this study showed that knowledge variable of nurses affected the completeness of inpatient nursing care filling on medical record, and it was statistically significant.

A study by Khoirunisa and fadilah (2017) stated that most of the nurses have good knowledge about nursing care documentation which was 41 nurses (83.7\%), and there was a significant relationship between the level of nurse knowledge about nursing documentation with the nurses' 
attitude in documenting the nursing care. Another study by Icon et al. (2016) stated that good knowledge significantly affected the nursing documentation. This was supported by Siamian et al. (2008) who stated that there was a significant relationship between knowledge and medical record documentation.

The nurse's knowledge determined the nurse's actions in providing services to the patient, therefore, the nurse's actions based on the knowledge would provide better service than the nurses who perform actions that were not based on the knowledge, therefore, knowledge was very influential on the completeness of nursing care documentation filling (Nuryani et al., 2014). In addition, according to Notoatmodjo (2010), knowledge was a very important factor to determine the actions of a person, so that the behavior based on the knowledge would be more long-lasting than the behavior which was not based on knowledge, it mean that the higher the knowledge of a person, it was expected that the better the behavior that she/he performed.

\section{5 . The effect of responsibility on the completeness of inpatient nursing care filling on medical record}

The result of this study showed that responsibility variable of nurses affected the completeness of inpatient nursing care filling on medical record, and it was statistically significant.

The result of a study by Ulum and Wulandari (2013) stated that most of the nurse team (83.3\%) has good responsibility. This responsibility was the responsebility of providing nursing care services and also in the recording. Another study done by Khoirunisa and Fadilah (2017) stated that 18 nurses agreed that nursing care documentation was the nurses' duty, and nurses have to be responsible for documenting every action given to the patients.

A study by Titis (2014), stated that nursing care documentation became an important matter as the evidence of responsibility and accountability of nurses in doing their duties. In addition, Nugraha (2012) stated thatthe nurses must be able to understand and fully understand their responsibilities as a nurse performed by writing the complete nursing documenttation on the prescribed sheet, because documenting nursing care was the personal responsibility of each nurse.

\section{The effect of organizational sup- port on the completeness of inpatient nursing care filling on medical record}

The result of this study showed that organizational support variable of nurses affected the completeness of inpatient nursing care filling on medical record, and it was statistically significant.

This study was in line with a study by Mandagi et al. (2015) which stated that there was a significant relationship between supervision of the leadership with the nurses' performances in applying nursing care, in addition, there was a significant relationship between the reward system and the performance of nurses in applying nursing care. A study by Saleem (2015) showed that the support from hospital organization would significantly improve the nurses' performances. In this study, the support from colleagues can improve the completeness of nursing care documentation filling (64.0\%). It was possible that support to other workers was always given due to the similarity of the profession.

This statement was in line with a study byUlum andWulandari (2013), which stated that the support from colleagues in doing a job was one of the important things, especially in the implementation of 
nursing care.Peer support was measured based on the implementation of nursing care conducted by the co-worker, and also the help from a colleague if the other nurse has difficulty. Co-workers who did nursing care properly would make other colleagues to be better in doing their job. Lack of recognition of well-performing employees, quality performance results, the absence of formal performance assessment systems, poor working condition, and incentives would affect the nurses' performance in completing nursing care documentation (Awases et al., 2013).

\section{REFERENCES}

$\overline{\text { Dehghan M, Dehghan D, Sheikhrabori A, }}$ Sadeghi M, Jalalian M (2013). Quality improvement in clinical documenttation: does clinical governance work?. Journal of Multidisciplinary Healthcare, 6: 441-450. http://doi.org/10.2147/JMDH.S53252

Hutagalung H (2005). Kajian Pemanfaatan Rekam Medis Sebagai Bahan Pengembangan Ilmu Pengetahuan dan Teknologi Kedokteran serta Perencanaan di RS Santa Elisabeth Medan Tahun 2005. Tesis. Medan: Program Magister Administrasi Rumah Sakit Program Studi Ilmu Kesehatan Masyarakat Universitas Sumatera Utara.

Icon MKO, Endris Y, Zegeye DT (2016). Nursing care documentation practice: The unfinished task of nursing care in the University of Gondar Hospital. Journal Informatics for Health and Social Care, 42(3): 290-302. https://doi.org/10.1080/17538157.2016.1252 766.

Jefferies D, Johnson M, Griffiths R (2010). A meta-study of the essentials of quality nursing documentation. International Journal of Nursing Practice,
16(2): 112-124. http://doi.org/10.1111/j.1440-172X.2009.01815.x

Kumajas FW, Warouw H, Bawotong J (2014). Hubungan Karakteristik Individu Dengan Kinerja Perawat Di Ruang Rawat Inap Penyakit Dalam Rsud Datoe Binangkang Kabupaten Bolaang Mongondow. Jurnal Keperawatan, 2(2). http://doi.org/10.1073/pnas.0703993104.

Khoirunisa V, Fadilah A (2017). Hubungan antara tingkat pengetahuan perawat tentang dokumentasi keperawatan dengan sikap perawat dalam pendokumentasian asuhan keperawatan di ruang rawat inap RSUD Dr.Loekmono Hadi Kudus. Prosiding HEFA, 419.

Mandagi FM, Umboh JML, Rattu JAM (2015). Analisis Faktor - Faktor Yang Berhubungan Dengan Kinerja Perawat Dalam Menerapkan Asuhan Keperawatan di Rumah Sakit Umum Bethesda Gmim Tomohon. Jurnal eBiomedik. 3(3): 884-894.

Maryati W, Murti B, Indarto D (2017). Factors Affecting the Quality of Diagnosis Coding and Medical Record at Dr. Moewardi Hospital, Surakarta. Journal of Health Policy And Management, 0281: 61-70. Retrieved from http://thejhpm.com/index.php?journ $\mathrm{al}=$ thejhpm\&page $=$ article $\& o p=$ view $\&$ path\%5B\%5D=13.

Menteri Kesehatan RI (2001). Keputusan Menteri Kesehatan Republik Indonesia Tentang Registrasi Dan Praktik Perawat, 1-23; http://doi.org/10.1017/CBO9781107415324.004.

(2008). Keputusan Menteri Kesehatan RI No. 129/MENKES/SK/II/2008 tentang Standar Pelayanan Minimal Rumah Sakit. Jakarta.

Moradi T, Maghaminejad F, Azizi-Fini I (2014). Quality of Working Life of Nurses and its Related Factors. 
Journal of Health Policy and Management (2018), 3(1): 1-10

https://doi.org/10.26911/thejhpm.2018.03.01.01

Nursing and Midwifery Studies, 3(2): e19450.

Nugraha ATH (2012). Hubungan Persepsi

Perawat Tentang Manfaat Dokumentasi Asuhan Keperawatan Dengan Kelengkapan Dokumentasi Asuhan Keperawatan Di Ruang Rawat Inap RS Pku Muhammadiyah Yogyakarta. Yogyakarta: STIKES Aisyiyah Yogyakarta.

Nursalam (2007). Manajemen Keperawatan Aplikasi Dalam Praktek Keperawatan. Jakarta: Salemba Medika.

(2009). Manajemen Keperawatan Aplikasi dalam Praktik Keperawatan Profesional. Edisi 2, Jakarta: Penerbit Salemba Medika.

Nuryani N, Susanti DD (2014). Hubungan Pengetahuan Perawat dengan Kelengkapan Dokumentasi Asuhan Keperawatan di RSUD dr. Soekardjo Kota Tasikmalaya. Jurnal Manajemen Informasi Kesehatan Indonesia, 1(1): 5-9.

Notoatmodjo S (2010). Kesehatan Masyarakat: Ilmu dan Seni. Jakarta: PT Rineka Cipta.

Okaisu EM, Kalikwani F, Wanyana G, Coetzee M (2014). Improving the quality of nursing documentation: An action research project. Journal Curationis, 38(1): 1-11.

Pratiwi PP, Suryani M, dan Sayono (2014). Hubungan Tingkat Pendidikan Dan Lama Kerja Dengan Kelengkapan Pengisian Dokumentasi Pengkajian Asuhan Keperawatan Di RSUD Tugurejo Semarang. 1-12.

Saleem A (2015). Selected Organizational Factors Affecting Performance of Professional Nurses in North West Bank Governmental Hospitals. Journal of Education and Practice, 6(7): 100111.
Sanjoyo R (2007). Sistem Informasi Kesehatan. KTI. Yogyakarta: UGM.

Siamian H, Ghafari AB, Aligolbandi K (2008). Study on Rate of Knowledge, Attitude and Practice of Medical Students Towards Method of Medical Records Documentation. World Journal of Medical Sciences, 3(2): 24-27.

Setz VG, D’Innocenzo M (2009). Evaluation of the quality of nursing documentation though the review of patient medical records. Acta Paulista de Enfermagem, 22(3): 313-317.

Titis S (2014). Hubungan Motivasi Kerja Perawat dengan Mutu Pendokumentasian Asuhan Keperawatan di Ruang Rawat Inap Penyakit Dalam RSUD Panembahan Senopati Bantul Yogyakarta. Yoyakarta: Program Studi Ilmu Keperawatan STIKES Aisyiyah Yogyakarta.

Triyanto E, Kamaluddin R (2008). Gambaran Motivasi Perawat Dalam Melakukan Dokumentasi Keperawatan Di Rsud Prof. Dr. Margono Soekarjo Purwokerto. Jurnal Keperawatan Soedirman, 3(2): 66-80.

Ufitinema Y, Wong R, Adomako E, Kanyamarere L, Ntagungira EK, Kagwiza J (2016). Increasing patient medical record completion by assigning nurses to specific patients in maternity ward at Munini hospital. On the Horizon, 24(4): 327-334.

Ulum MM, Wulandari RD (2013). Faktor Yang Mempengaruhi Kepatuhan Pendokumentasian Asuhan Keperawatan Berdasarkan Teori Kepatuhan Milgram. Administrasi Kesehatan Indonesia, 1: 252-262. 